\title{
Implementasi Komunikasi Wifi dalam Perancangan Lengan Robot
}

\author{
Aziz Octavianto ${ }^{1 *}$, Muhammad Ramdani ${ }^{1}$, Mujirudin $^{1}$, Harry Ramza $^{1}$, Yohannes Dewanto $^{2}$ \\ ${ }^{1}$ Program Studi Teknik Elektro, Fakults Teknik. Universitas Muhammadiyah Prof. Dr. HAMKA \\ Jalan Tanah Merdeka No 6, Kp Rambutan, Jakarta, Indonesia \\ Telp :+62-21-8400341, Faks : +62-21-8411531,*Email :azizocta@gmail.com \\ muhammadramdani@uhamka.ac.id,mujirudin@uhamka.ac.id; hramza@uhamka.ac.id; \\ ${ }^{2}$ Program Studi Teknik Elektro, Fakultas Teknik. Universitas Suryadarma \\ Jalan Protokol Halim Perdanakusuma Komplek Bandara, Jakarta, Indonesia \\ Telp : +62-21-8009249, Faks : + 62-21-8009246, Email : dewantoyohanes@gmail.com
}

\begin{abstract}
Abstrak -Keberadaan teknologi robotika saat ini sangat membantu dalam aktivitas manusia untuk mempermudah melakukan perkerjaan. Salah satu teknologi robotika saat ini yaitu lengan robot. Lengan robot merupakan jenis robot yang menyerupai lengan manusia yang dapat memindahkan barang dari satu tempat menuju tempat lainnya. Namun ketika lengan robot ditempatkan pada area yang memiliki kondisi lingkungan yang ekstrim, maka lengan robot tersebut harus dilengkapi dengan sebuah sistem pengendali jarak jauh. Penelitian ini bertujuan untuk merancanglengan robot yang memiliki 4 derajat kebebasan dan mampu dikendalikan dari jarak jauh melalui komunikasi wifi dengan menentukan nilai waktu tunda. Lengan robot dirancang menggunakan mikrokontroler NodeMCU ESP-12E dimana mikrokontroler tersebut sudah memiliki fitur untuk terhubung kedalam jaringan WiFi. Lengan robot memiliki lima buah motor servo dan dapat bergerak berdasarkan empat bagian yaitu base, shoulder, elbow, dan wrist serta sebagai end-effectornya adalah gripper. Hasil penelitian menunjukkan bahwa lengan robot mampu dikendalikan dengan jarak jangkauan maksimum sejauh 16 meter dan memiliki rata-rata waktu tunda sebesar $66.6 \mathrm{~ms}$.
\end{abstract}

Kata kunci: Lengan Robot, 4 DOF, Komunikasi Wifi, Motor Servo, Mikrokontroler, NodeMCU

\section{Pendahuluan}

Keberadaan teknologi robotika saat ini sangat membantu dalam aktivitas manusia untuk mempermudah melakukan perkerjaan. Salah satu teknologi robotika saat ini yaitu lengan robot.

Lengan robot atau biasa disebut dengan robot manipulator terdiri dari gabungan dari beberapa segmen dan joint yang dibagi menjadi empat bagian yaitu base, elbow, shoulder dan gripper [1]. Secara umum lengan robot merupakan alat mekanik yang menggantikan tugas manusia yang berhubungan dengan perkerjaan fisik yang sifatnya berulangulang, mempunyai resiko tinggi seperti mengangkat barangbarang berat dari satu tempat ke tempat lain, melakukan pekerjaan cepat, presisi, dan membutuhkan daya tahan serta konsentrasi tinggi [2]. Namun ketika lengan robot ditempatkan pada area yang memiliki kondisi lingkungan yang ekstrim, maka lengan robot tersebut harus dilengkapi dengan sebuah sistem pengendali jarak jauh.

Lengan robot dirancang menggunakan mikrokontroler NodeMCU V.3 Lollin dimana mikrokontroler tersebut sudah memiliki fitur untuk terhubung kedalam jaringan WiFi. Lengan robot memiliki 5 buah motor servo dan dapat bergerak berdasarkan empat bagian actuator yaitu base,shoulder, elbow, dan wrist serta sebagai end-effectornya adalah gripper.

\section{Dasar Teori}

\subsection{Lengan Robot}

Lengan robot memilliki tiga bagian utama yaitu struktur bagian mekanik, bagian penggerak (actuator), dan bagian elektrik. Bagian mekanik merupakan bagian yang terdiri dari susunan rangka lengan robot yang terhubung satu sama lain oleh joint (sendi) dan link (penghubung tiap joint).

Lengan robot dapat bergerak menggunakan lima buah motor servo sebagai aktuatornya yang bergerak berdasarkan empat bagian yaitu base, shoulder, elbow, dan wrist sertasebagai end-effectornyaadalah gripper. Derajat kebebasan (Degree of Freedom) adalah sambungan pada lengan yangdapat diputar maupun digeser. Derajat kebebasan digunakan untuk mengetahui cara robot bergerak dan jumlah aktator lengan robot yang digunakan.

Kinematika adalah studi yang mempelajari pergerakan robot tanpa memperhatikan gaya yang mempengaruhi pergerakan lengan robot. Pada sebuah analisis kinematic, posisi, kecepatan dan akselerasi dari seluruh link dihitung tanpa memperhatikan gaya yang menyebabkan pergerakan tersebut 
Kinematika lengan robot 2 sendi ditunjukkan pada Gambar 1 dibawah ini.

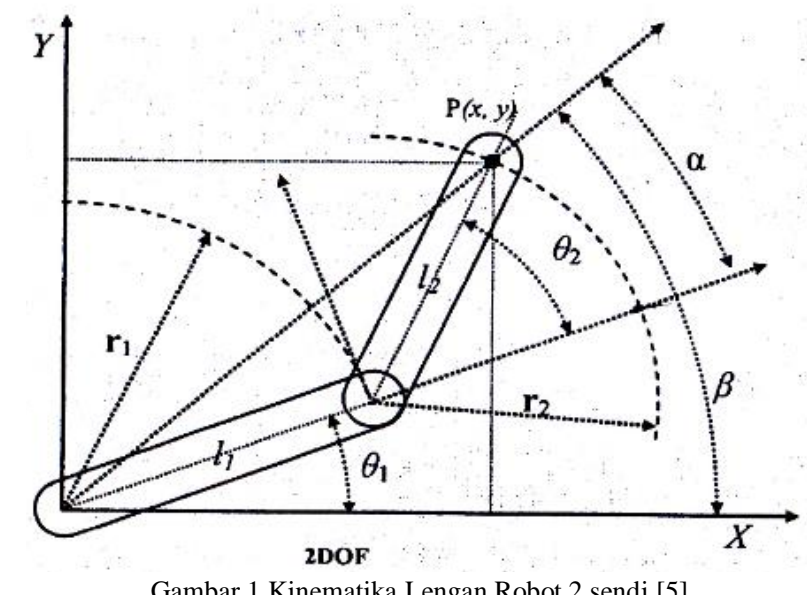

Invers Kinematik lengan robot dua sendi pada gambar 2.22 dapat dijabarkan menggunakan rumus trigonometri secara forward kinematika. Kedudukan ujung lengan dinyatakan sebagai $\mathrm{P}(\mathrm{x}, \mathrm{y})$, dengan:

$$
P(x, y)=f\left(\theta_{1}, \theta_{1}\right)
$$

Jika $\mathrm{p}$ diasumsikan sebagai vektor penjumlahan yang terdiri dari vektor $\mathrm{r} 1$ lengan-1 dan $\mathrm{r} 2$ lengan $\mathrm{r} 2$, yaitu :

$$
\begin{aligned}
& r_{1}=\left[l_{1} \cos \theta_{1} \cdot l_{2} \cos \left(\theta_{1}\right]\right. \\
& r_{2}=\left[l_{2} \cos \left(\theta_{1}+\theta_{2}\right) \cdot l_{2} \operatorname{Sin}\left(\theta_{1}+\theta_{2}\right)\right]
\end{aligned}
$$

Maka,

$$
\begin{aligned}
& x=l_{1} \cos \theta_{1}+l_{2} \cos \left(\theta_{1}+\theta_{2}\right) \\
& y=l_{1} \cos \theta_{1}+l_{2} \cos \left(\theta_{1}+\theta_{2}\right)
\end{aligned}
$$

Persamaan (3) dan (4) dapat diperoleh menggunakan analisis kinematika maju dengan hukum identitas trigonometri:

$$
\begin{aligned}
& \cos (a+b)=\cos (a) \cos (b)-\sin (a) \sin (b) \\
& \sin (a+b)=\sin (a) \cos (b)-\sin (b) \cos (a)
\end{aligned}
$$

maka didapatkan:

$$
\begin{gathered}
P x=l_{1} \cos \left(\theta_{1}\right)+l_{2} \cos \left(\theta_{1}\right) \cos \left(\theta_{2}\right)- \\
l_{2} \sin \left(\theta_{1}\right) \sin \left(\theta_{2}\right) \\
P y=l_{1} \sin \left(\theta_{1}\right)+l_{2} \sin \left(\theta_{1}\right) \cos \left(\theta_{2}\right)- \\
l_{2} \cos \left(\theta_{1}\right) \sin \left(\theta_{2}\right)
\end{gathered}
$$

Dari Persamaan (7) dan (8) serta menggunakan analisis kinematika balik, maka akan didapatkan:

$$
\theta_{2}=\cos ^{-1}\left\{\frac{x^{2}+y^{2}-l_{1}^{2}-l_{2}^{2}}{2 l_{1} l_{2}}\right\}
$$

Sedangkan sudut $\theta_{1}$ dapat dicari melalui,

$$
\tan \alpha=\frac{l_{2} \sin \theta_{2}}{l_{2} \cos \theta_{2}+l_{1}} \text { dan } \tan \beta=\frac{y}{x}
$$

sudut dapat dicari melalui $\theta 1$ dapat dicari melalui

$$
\theta_{1}=\beta-\alpha
$$

Dengan hukum identitas trigonometri :

didapatkan:

$$
\tan \mathrm{a}+\mathrm{b}=\frac{\tan a-\tan b}{1+\sin a \sin b}
$$

Sehingga

$$
\tan \theta_{1}=\frac{y \cdot l_{1}+l_{2 \cos } \theta_{2}-x . l_{2 \sin } \theta_{2}}{x . l_{1}+l_{2 \cos } \theta_{2}-y \cdot l_{2 \sin } \theta_{2}}
$$

$$
\theta_{1}=\tan ^{-1} \frac{y \cdot l_{1}+l_{2} \cos \theta_{2}-x \cdot l_{2 \sin } \theta_{2}}{x \cdot l_{1}+l_{2} \cos \theta_{2}-y \cdot l_{2 \sin } \theta_{2}}
$$

Dengan penjabaran trigonometri maka persamaan (1) sampai (14) merupakan persamaan dari invers kinematika lengan robot dua sendi.

\subsection{Node Micro Controller Unit (NodeMCU) V.3 Lollin}

NodeMCU (Node Micro Controller Unit) merupakan sebuah platform Internet of Things yang bersifat opensource. NodeMCU dikembangkan berdasarkan pada modul ESP8266 yang mengintegrasikan GPIO, PWM (Pulse Width Modulation), IIC, Wire, dan ADC (Analog to Digital Converter). mikrokontroller ini dilengkapi fitur wifi dan firmware yang bersifat open source.

NodeMCU dapat berfungsi sebagai host maupun sebagai modul transfer data dalam jaringan WiFi. Mikrokontroller ini memiliki kemampuan pengolahan dan penyimpanan data yang baik sehingga memungkinkan untuk diintegrasikan dengan sensor dan perangkat khusus lainnya melalui GPIO (general pin input output) [3]. Bentuk fisik NodeMCU dapat dilihat pada gambar 2 .

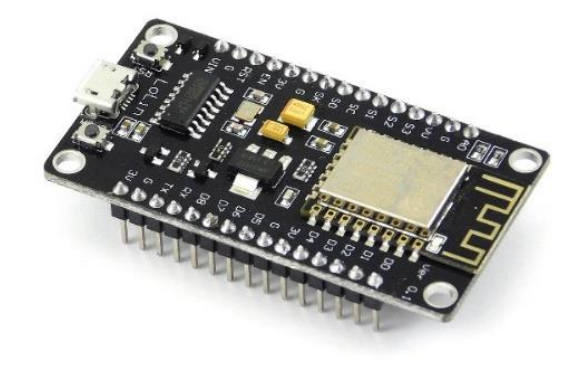

Gambar 2 Bentuk Fisik NodeMCU V.3 Lollin [6]

Jantung dari NodeMCU adalah unit chip mikrokontroler ESP12 CORE. dimana chip mikrokontroler ini sudah tertanam antenna microstrip. NodeMCU dipetakan agar setiap kakinya (pin) selalu sama dengan board NodeMCU versi lainnya, hal ini berguna agar setiap board NodeMCU saling kompatibel [6]. Peta pin ESP-12E dapat dilihat pada gambar 3

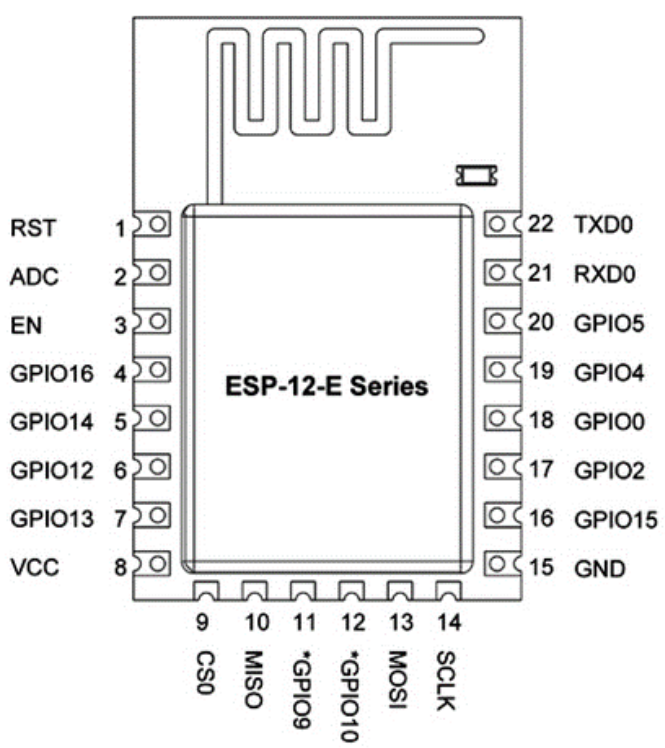

Gambar 3 Peta pin chip mikrokontroler ESP12-E [6] 
Berikut adalah spesifikasi dari NodeMCU V.3 Lollin

Tabel 1 Spesifikasi NodeMCU V.3 Lollin

\begin{tabular}{ll}
\hline \multicolumn{1}{c}{ SPESIFIKASI } & \multicolumn{1}{c}{ NodeMCU V.3 Lollin } \\
\hline Mikrokontroller & ESP12-E \\
Ukuran Board & $57 \mathrm{~mm}$ x $30 \mathrm{~mm}$ \\
Tegangan Kerja & $3.3 \mathrm{~V} \sim 5 \mathrm{~V}$ \\
Wifi & IEEE $802.11 \mathrm{~b} / \mathrm{g} / \mathrm{n}$ \\
& $802.11 \mathrm{~b}:+16 \pm 2 \mathrm{dBm}$ (at 11 \\
& $\mathrm{Mbps})$ \\
& $802.11 \mathrm{~g}:+14 \pm 2 \mathrm{dBm}$ (at 54 \\
Power Transmisi & $\mathrm{Mbps})$ \\
& $802.11 \mathrm{n}:+13 \pm 2 \mathrm{dBM}$ (at HT20, \\
& $\mathrm{MCS} 7)$ \\
Range Frekuensi & $2.412 \mathrm{Ghz} \sim 2.484 \mathrm{Ghz}$ \\
Wireless Form & On board PCB antenna mikrostrip \\
Serial Transmisi & $110-921600 \mathrm{bps}, \mathrm{TCP}$ Client 5 \\
Network Protokol & $\mathrm{IPv} 4, \mathrm{TCP} / \mathrm{UDP} / \mathrm{FTP} / \mathrm{HTTP}$ \\
IO Capability & $\mathrm{UART}, 12 \mathrm{C}, \mathrm{PWM}, \mathrm{GPIO}, 1 \mathrm{ADC}$ \\
Temperatur operasi & $40 \sim 125^{\circ} \mathrm{C}$ \\
Flash Memory & $4 \mathrm{Mb}$ \\
Clock speed & $40 / 26 / 24 \mathrm{Mhz}$ \\
Usb to serial coverter & $\mathrm{CH} 340 \mathrm{G}$ \\
USB port & $\mathrm{Micro}$ USB \\
\hline
\end{tabular}

\subsection{Motor Servo}

Motor servo adalah sebuah motor DC yang dilengkapi rangkaian kontrol dengan sistem umpan balik tertutup. Pada motor servo posisi dari motor akan diinformasikan kembali kerangkaian kontrol yang ada di dalam motor servo [3]. Skematik rangkaian kontrol motor servo dapat dilihat pada gambar 4.

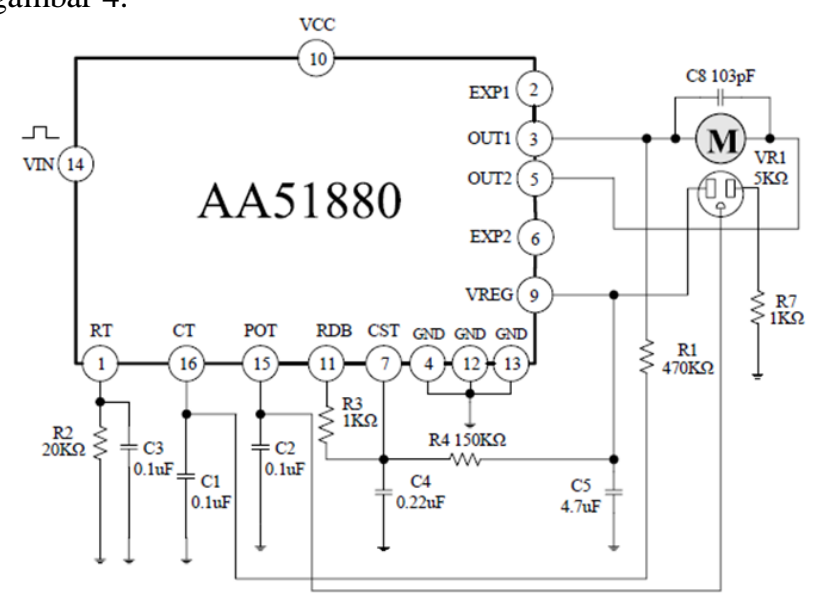

Gambar 4 Skematik Rangkaian Kontrol Elektrik Motor Servo [8]

\section{Metodologi Penelitian}

\subsection{Perancangan Lengan Robot}

Pada perancangan lengan robot menggunakan 5 buah motor servo sebagai actuator dimana masing-masing motor servo diletakkan ditempat yang berbeda tergantung dari torsi yang dihasilkan oleh motor servo tersebut.

Gambar 5 merupakan perancangan mekanik lengan robot dimana lima bagian utama pada robot tersebut berperan sebagai penghubung (link), yang meliputi :

1. Bagian dasar (Base)

2. Bagian bahu (Shoulder)

3. Bagian Siku (Elbow)
4. Bagian Pergelangan (Wrist)

5. Bagian ujung yang diberi gear penjepit (End effector)

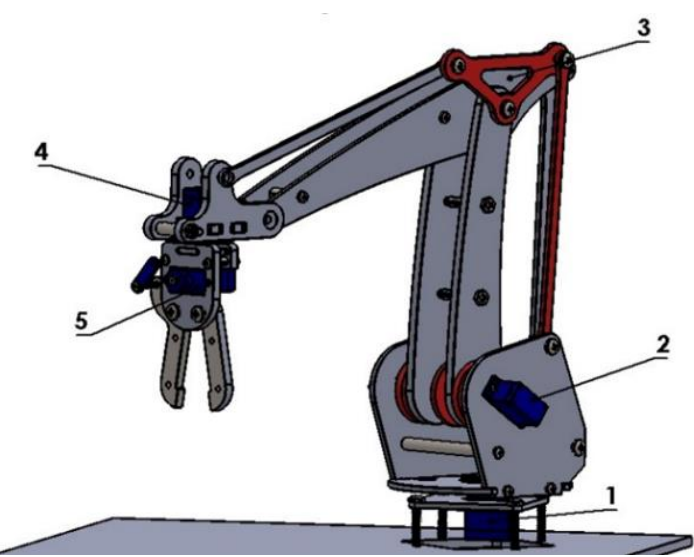

Gambar 5 Perancangan Mekanik Lengan Robot

Tabel 2 Spesifikasi Lengan Robot

\begin{tabular}{ccccc}
\hline No & $\begin{array}{c}\text { Lengan } \\
\text { penghubung } \\
\text { (joint) }\end{array}$ & $\begin{array}{c}\text { Panjang setiap } \\
\text { bagian lengan }\end{array}$ & $\begin{array}{c}\text { Sensifitas } \\
\text { sudut }\end{array}$ & $\begin{array}{c}\text { Sudut } \\
\text { maksimum yang } \\
\text { dapat dijangkau }\end{array}$ \\
\hline 1 & Penjepit (Gripper) & $7 \mathrm{~cm}$ & $0^{\circ}-40^{\circ}$ & $40^{\circ}$ \\
2 & Pergelangan (wrist) & $5.5 \mathrm{~cm}$ & $0^{\circ}-180^{\circ}$ & $180^{\circ}$ \\
3 & Siku (Elbow) & $21.4 \mathrm{~cm}$ & $100^{\circ}-180^{\circ}$ & $80^{\circ}$ \\
4 & Bahu (shoulder) & $14.8 \mathrm{~cm}$ & $10^{\circ}-120^{\circ}$ & $110^{\circ}$ \\
5 & Dasar (base) & $9 \mathrm{~cm}$ & $0^{\circ}-180^{\circ}$ & $180^{\circ}$ \\
\hline & & & &
\end{tabular}

\subsection{Perancangan Rangkaian Motor Servo}

Motor servo yang digunakan berjumlah 5 buah, 4 buah untuk menggerakkan lengan dan 1 buah untuk menggerakkan gripper. Masing -masing motor servo baik yang digunakan pada lengan ataupun motor servo yang digunakan pada gripper agar dapat berfungsi dengan baik membutuhkan tegangan 5 VDC. Skematik rangkaian motor servo ditunjukkan pada gambar 6 .
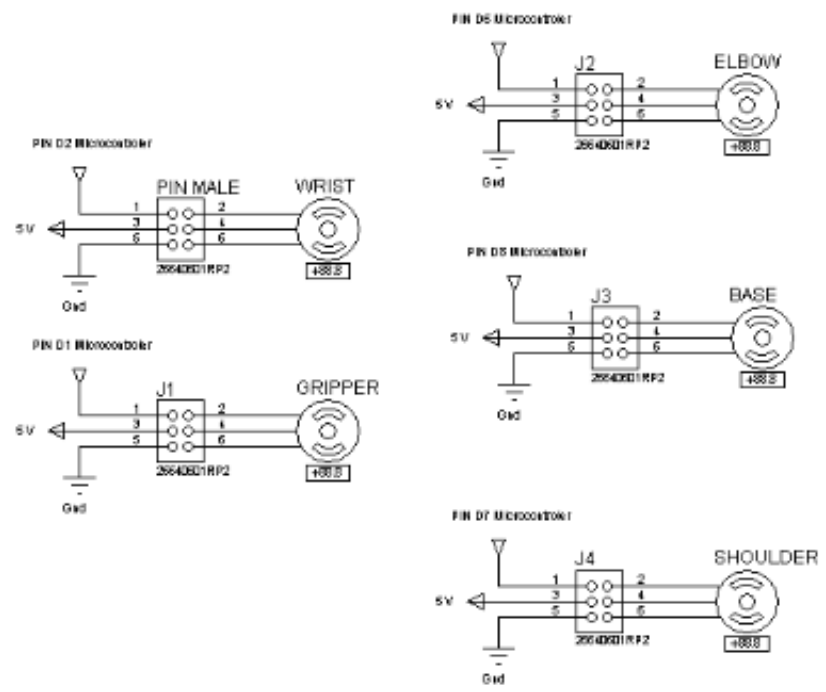

Gambar 6 Skematik Rangkaian Motor Servo 


\subsection{Perancangan Antarmuka Aplikasi Lengan Robot}

Untuk menggerakkan lengan robot dari jarak jauh melalui koneksi jaringan Wifi, penulis memanfaatkan aplikasi yang sudah tersedia pada "Play store" android. Dengan kata kunci "BLYNK", aplikasi ini sebagai remote control untuk mengirimkan perintah ke lengan robot. antarmuka untuk menggerakkan lengan robot dirancang seperti gambar7.

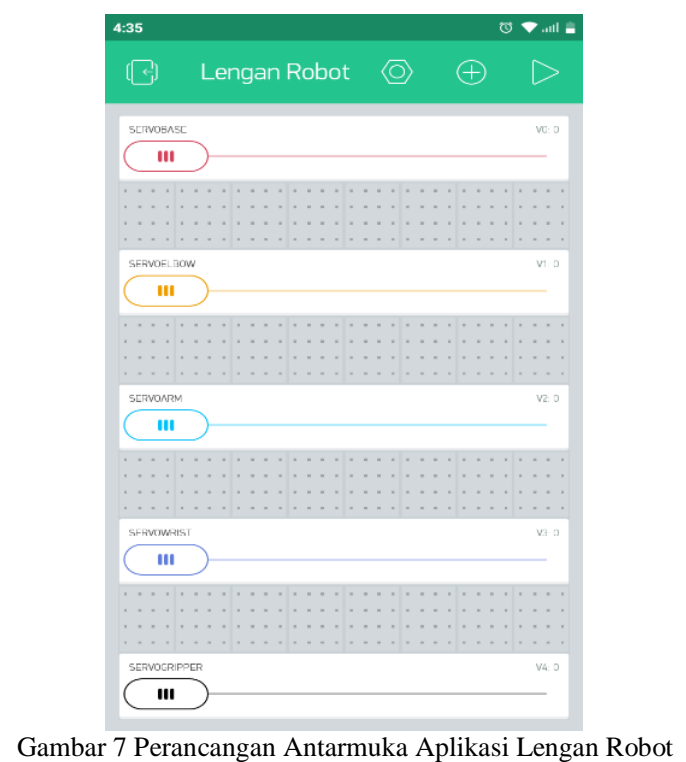

\section{Temuan dan Pembahasan}

\subsection{Hasil Perancangan Lengan Robot}

Hasil dari perancangan lengan robot ini terdiri dari kerangka yang saling dihubungkan membentuk lengan robot yang sebagian besar terbuat dari bahan akrilik dengan ketebalan 3 $\mathrm{mm}$.

Lengan robot inimemiliki 4 derajat kebebasan yang biasa disebut dengan DOF (Degree of Freedom), yang terdiri dari base, shoulder, elbow, wrist, dan gripper sebagai end effector. Selain itu terdapat juga link dan joint yang ada dalam mekanik lengan robot. Hasil dari perancangan lengan robot dapat dilihat pada gambar 8 .

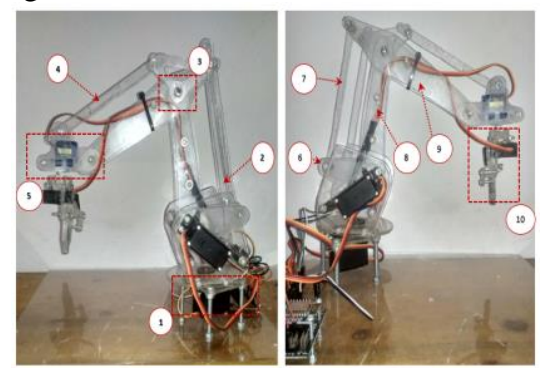

Gambar 8 Hasil Perancangan Lengan Robot

Keterangan pada gambar 8 .

1. Nomor 1 merupakan bagian base lengan robot

2. Nomor 2 merupakan link 1 wrist lengan robot

3. Nomor 3 merupakan bagian joint untuk menghubungkan link 1 wrist dengan link 2 wrist.

4. Nomor 4 merupakan link 2 wrist lengan robot

5. Nomor 5 merupakan bagian wrist lengan robot

6. Nomor 6 merupakan joint untuk menggerakkan elbow
7. Nomor 6 merupakan link untuk menggerakkan elbow

8. Nomor 8 merupakan rangka bagian shoulder lengan robot

9. Nomor 9 merupakan rangka bagian elbow lengan robot

10. Nomor 10 merupakan bagian end effector yaitu gripper

\subsection{Pengujian Lengan Robot}

\subsubsection{Pengujian Sudut Lengan Robot}

Pengujian sudut lengan robot dilakukan untuk mengetahui jangkauan maximum dan minimum lengan robot dengan cara mengukur nilai sudut $\mathrm{x}$ dan $\mathrm{y}$ serta membandingkan sudut servo dengan sudut terukur pada bagian servo elbow dan servo shoulder.Hasil pengujian sudut lengan robot dengan cara menentukan nilai terukur $\mathrm{x}$ dan y serta membandingkan sudut servo dengan sudut terukur ditunjukkan pada tabel 3 dibawah ini

\begin{tabular}{|c|c|c|c|c|c|c|}
\hline \multirow[t]{2}{*}{ No } & \multicolumn{2}{|c|}{$\begin{array}{c}\text { Sudut Servo } \\
\left({ }^{0}\right)\end{array}$} & \multicolumn{2}{|c|}{$\begin{array}{l}\text { Sudut Terukur } \\
\left({ }^{0}\right)\end{array}$} & \multicolumn{2}{|c|}{$\begin{array}{c}\text { Jarak Jangkau } \\
\text { Lengan Robot } \\
\text { (Cm) }\end{array}$} \\
\hline & Elbow & Shoulder & Elbow & Shoulder & $\mathbf{x}$ & $\mathbf{y}$ \\
\hline 1 & $180^{\circ}$ & $10^{\circ}$ & $178^{\circ}$ & $18^{\circ}$ & 8.5 & 8 \\
\hline 2 & $180^{\circ}$ & $20^{\circ}$ & $178^{\circ}$ & $27^{\circ}$ & 8.5 & 8 \\
\hline 3 & $180^{\circ}$ & $30^{\circ}$ & $178^{\circ}$ & $35^{\circ}$ & 9 & 8 \\
\hline 4 & $180^{\circ}$ & $40^{\circ}$ & $178^{\circ}$ & $45^{\circ}$ & 9 & 8.5 \\
\hline 5 & $180^{\circ}$ & $50^{\circ}$ & $178^{\circ}$ & $53^{\circ}$ & 9 & 9.5 \\
\hline 6 & $180^{\circ}$ & $60^{\circ}$ & $175^{\circ}$ & $65^{\circ}$ & 12 & 8 \\
\hline 7 & $180^{\circ}$ & $70^{\circ}$ & $175^{\circ}$ & $73^{\circ}$ & 14 & 7.5 \\
\hline 8 & $180^{\circ}$ & $80^{\circ}$ & $175^{\circ}$ & $90^{\circ}$ & 16 & 5.5 \\
\hline 9 & $180^{\circ}$ & $90^{\circ}$ & $175^{\circ}$ & $95^{\circ}$ & 17 & 5 \\
\hline 10 & $180^{\circ}$ & $100^{\circ}$ & $170^{\circ}$ & $105^{\circ}$ & 19 & 4 \\
\hline 11 & $180^{\circ}$ & $110^{\circ}$ & $170^{\circ}$ & $117^{\circ}$ & 20 & 2 \\
\hline 12 & $180^{\circ}$ & $120^{\circ}$ & $170^{\circ}$ & $123^{\circ}$ & 21 & 0 \\
\hline 13 & $170^{\circ}$ & $50^{\circ}$ & $180^{\circ}$ & $58^{\circ}$ & 16 & 7 \\
\hline 14 & $160^{\circ}$ & $50^{\circ}$ & $170^{\circ}$ & $58^{\circ}$ & 14 & 6.5 \\
\hline 15 & $150^{\circ}$ & $50^{\circ}$ & $165^{\circ}$ & $55^{\circ}$ & 13 & 5 \\
\hline 16 & $140^{\circ}$ & $50^{\circ}$ & $150^{\circ}$ & $55^{\circ}$ & 12 & 4.5 \\
\hline 17 & $130^{\circ}$ & $50^{\circ}$ & $135^{\circ}$ & $53^{\circ}$ & 11 & 4 \\
\hline 18 & $120^{\circ}$ & $50^{\circ}$ & $130^{\circ}$ & $53^{\circ}$ & 11 & 3 \\
\hline 19 & $110^{\circ}$ & $50^{\circ}$ & $120^{\circ}$ & $50^{\circ}$ & 11 & 2 \\
\hline 20 & $100^{\circ}$ & $50^{\circ}$ & $105^{\circ}$ & $50^{\circ}$ & 10.5 & 1 \\
\hline
\end{tabular}

Berdasarkan pada tabel 3 maka didapatkan hasil Errorsendi Shouder antara sudut servo dengan sudut terukur yang dapat dilihat pada tabel 4 dibawah ini

\begin{tabular}{cccc}
\multicolumn{4}{c}{ Tabel } \\
\hline No Hasil Pengujian & Sudut Servo & $\begin{array}{c}\text { Sudut } \\
\text { Terukur }\end{array}$ & Error \\
\hline 1 & $10^{\circ}$ & $18^{\circ}$ & $44.4 \%$ \\
2 & $20^{\circ}$ & $27^{\circ}$ & $25.9 \%$ \\
3 & $30^{\circ}$ & $35^{\circ}$ & $14.2 \%$ \\
4 & $40^{\circ}$ & $45^{\circ}$ & $11.11 \%$ \\
5 & $50^{\circ}$ & $53^{\circ}$ & $5.66 \%$ \\
6 & $60^{\circ}$ & $65^{\circ}$ & $7.69 \%$ \\
7 & $70^{\circ}$ & $73^{\circ}$ & $4.1 \%$ \\
8 & $80^{\circ}$ & $90^{\circ}$ & $20 \%$ \\
9 & $90^{\circ}$ & $95^{\circ}$ & $11.11 \%$ \\
10 & $100^{\circ}$ & $105^{\circ}$ & $4.76 \%$ \\
11 & $110^{\circ}$ & $117^{\circ}$ & $5.98 \%$ \\
12 & $120^{\circ}$ & $123^{\circ}$ & $2.43 \%$ \\
\hline
\end{tabular}

Berdasarkan pada tabel 4 data diambil sebanyak 12 kali percobaan didapatkan nilai error sudut yang diinput dengan sudut yang terukur. Nilai error terendah yaitu $2.43 \%$ nilai tersebut didapatkan pada saat sendi shoulder berada posisi 
terukur $123^{\circ}$ dan sudut servo berada pada posisi $120^{\circ}$. Grafik antara sudut yang diinput dengan sudut yang terukur pada sendi Shoulder ditunjukkan pada gambar 9 dibawah ini.

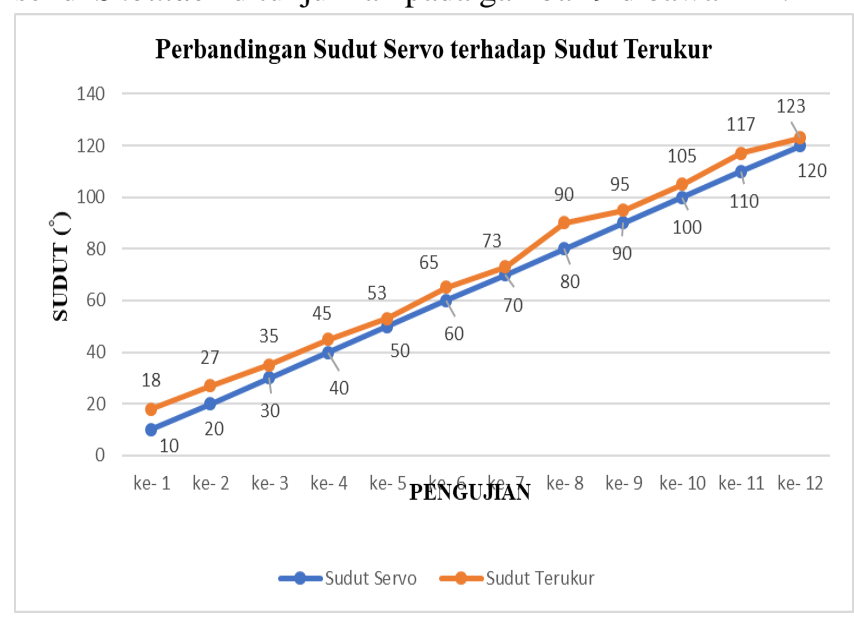

Gambar 9 Grafik Perbandingan Sudut Servo terhadap Sudut Terukur pada Sendi Shoulder

Pada bagian sendi elbow menggunakan penggerak yang dirancang seperti tuas untuk menggerakkan sendinya, jadi motor servo elbow tidak langsung menggerakkan sendinya seperti pada bagian lengan robot lainnya. Pada bagian sendi elbow untuk menggerakkan sendinya menggunakan joint pembantu sehingga letak perancangan motor servo elbow berada dibawah berdampingan dengan motor servo shoulder. Berikut tabel 5 yang menunjukkan hasil pengambilan data selisih sudut servo dengan sudut terukur.

\begin{tabular}{cccc}
\multicolumn{4}{c}{ Tabel 5 Hasil Pengujian Error pada Sendi Elbow } \\
\hline No & Sudut Servo & $\begin{array}{c}\text { Sudut } \\
\text { Terukur }\end{array}$ & Error \\
\hline 1 & $180^{\circ}$ & $170^{\circ}$ & $5.88 \%$ \\
2 & $170^{\circ}$ & $180^{\circ}$ & $5.5 \%$ \\
3 & $160^{\circ}$ & $170^{\circ}$ & $5.8 \%$ \\
4 & $150^{\circ}$ & $165^{\circ}$ & $9.09 \%$ \\
5 & $140^{\circ}$ & $150^{\circ}$ & $6.6 \%$ \\
6 & $130^{\circ}$ & $135^{\circ}$ & $3.7 \%$ \\
7 & $120^{\circ}$ & $130^{\circ}$ & $7.69 \%$ \\
8 & $110^{\circ}$ & $120^{\circ}$ & $8.33 \%$ \\
9 & $100^{\circ}$ & $105^{\circ}$ & $4.76 \%$ \\
\hline
\end{tabular}

Pada tabel 5 data pada sendi elbow diambil dari sudut maksimal ke sudut minimal. Sudut input maksimal mencapai nilai $180^{\circ}$ dan sudut minimal mencapai $100^{\circ}$. Grafik antara sudut yang diinput dengan sudut yang terukur pada sendi Elbow ditunjukkan pada gambar 10 dibawah ini.

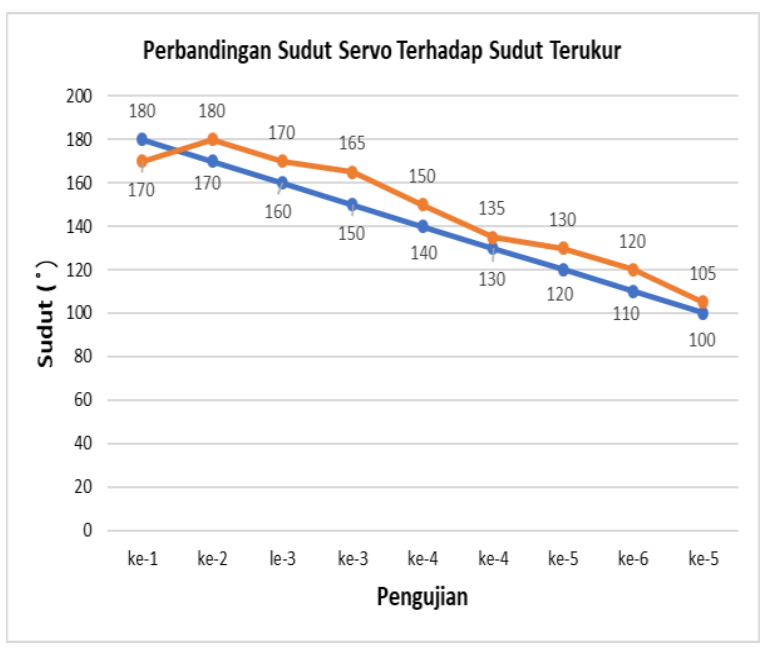

Gambar 10 Grafik Perbandingan Sudut Servo terhadap Sudut Terukur pada Sendi Elbow

\subsubsection{Pengujian Kinerja Gripper dan Menentukan Beban Angkat Maximum Lengan Robot}

Pengujian kinerja gripper dan menentukan beban angkat maximum lengan robot dilakukan sebanyak lima belas kali percobaan dengan obyek yang berbeda-beda. Pengulangan pengambilan obyek sebanyak tiga kali lalu diambil kesimpulan hasil pengamatannya. Hasil dari pengujian ini ditampilkan pada tabel 6

Tabel 6 Hasil Pengujian kinerja Gripper dan Menentukan Beban Angkat

\begin{tabular}{|c|c|c|c|c|c|c|}
\hline No & $\begin{array}{c}\text { Bentuk } \\
\text { objek }\end{array}$ & $\begin{array}{l}\text { Dimensi } \\
(\mathrm{cm})\end{array}$ & $\begin{array}{c}\text { Berat } \\
\text { (Gram) }\end{array}$ & Permukaan & $\begin{array}{c}\text { Waktu } \\
\text { Translasi } \\
\text { (Detik) }\end{array}$ & $\begin{array}{c}\text { Hasil } \\
\text { Pengamatan }\end{array}$ \\
\hline 1 & Heatsink & $2.5 \times 2 \times 1.4$ & 10.7 & Kasar & 10.5 & Baik \\
\hline 2 & Relay SPDT & $1.5 \times 2 \times 1.5$ & 11.5 & Licin & 11.2 & Baik \\
\hline 3 & Penghapus & $2 \times 2 \times 1$ & 12.2 & Kasar & 11.4 & Baik \\
\hline 4 & $\begin{array}{c}\text { Motor servo } \\
\text { SG90 }\end{array}$ & $\begin{array}{c}2.2 \times 2.2 \times \\
1.2\end{array}$ & 12.6 & Licin & 12.4 & Baik \\
\hline 5 & $\begin{array}{c}\text { Motor servo } \\
\text { MG90S }\end{array}$ & $\begin{array}{c}2.2 \times 2.2 \times \\
1.2\end{array}$ & 13.7 & Licin & 12.3 & Bergeser \\
\hline 6 & $\begin{array}{c}\text { Kotak Battry } \\
3.7 \mathrm{~V}\end{array}$ & $7.5 \times 4 \times 1.3$ & 17.3 & Kasar & 12.2 & Baik \\
\hline 7 & $\begin{array}{l}\text { Motor DC } \\
\text { gearbox }\end{array}$ & $6.3 \times 1.8 \times 2$ & 28.3 & Kasar & 13.8 & Bergeser \\
\hline 8 & $\begin{array}{c}\text { Battry AA } \\
1.5 \mathrm{~V}\end{array}$ & $4.8 \times 1.2$ & 28.3 & Licin & - & Terlepas \\
\hline 9 & $\begin{array}{l}\text { Cartridge } \\
\text { Printer }\end{array}$ & $4.5 \times 3 \times 4.2$ & 30 & Licin & - & Terlepas \\
\hline 10 & $\begin{array}{l}\text { Sensor load } \\
\quad \text { cell }\end{array}$ & $8 \times 1.2 \times 1.2$ & 32.3 & Kasar & 13.4 & Bergeser \\
\hline 11 & $\begin{array}{c}\text { Shield } \\
\text { Arduino } \\
\text { Nano }\end{array}$ & $5.7 \times 5.2 \times 1$ & 33.3 & Kasar & 12.7 & Bergeser \\
\hline 12 & Battry $3.7 \mathrm{~V}$ & $6.5 \times 1.8$ & 36.1 & Licin & - & Terlepas \\
\hline 13 & Battry $9 \mathrm{~V}$ & $2.5 \times 2 \times 1.4$ & 45 & Licin & - & Terlepas \\
\hline 14 & $\begin{array}{c}\text { Motor Servo } \\
\text { Futaba } \\
\text { S3003 }\end{array}$ & $4 \times 3.7 \times 2$ & 48 & Licin & - & Tidak Kuat \\
\hline 15 & Kotak Isolasi & $7 \times 7 \times 2.5$ & 46 & Kasar & - & Tidak Kuat \\
\hline
\end{tabular}


Berdasarkan tabel 6 dapat dilihat bahwa gripper akan mengalami kegagalan dalam pencengkraman objek apabila permukaan objek licin dan bobotnya cukup besar. Beban maximum yang mampu diangkat oleh lengan robot sebesar 33.3 gram dengan dimensi $5.7 \times 5.2 \times 1$

\subsection{Pengujian Rangkaian Cayu Daya (Power Supply)}

Pengujian dilakukan dengan menghubungkan catu daya dengan sumber tegangan AC 220 volt. Kemudian, keluaran dari catu daya diukur dengan multitester untuk mengetahui besarnya tegangan yang keluar dari catu daya tersebut. Dari hasil pengukuran tegangan dapat diketahui keluaran catu daya tersebut yang menjadi kebutuhan komponen pada lengan robot. hasil pengukuran catu daya yang ditunjukkan pada tabel 7 dibawah ini.

Tabel 7 Hasil Pengujian Catu Daya

\begin{tabular}{ccc}
\hline Tegangan Input & $\begin{array}{c}\text { Tegangan } \\
\text { Output }\end{array}$ & $\begin{array}{c}\text { Tegangan } \\
\text { Multimeter }\end{array}$ \\
\hline 220 VAC & 5 VDC & 5.4 VDC \\
\hline
\end{tabular}

Berdasarkan pada tabel 7 maka hasil pengukuran rangkaian catudaya yang diukur mengunakan multitester didapatkan nilai tegangannya sebesar 5,4 VDC yang seharusnya 5 VDC sesuai dengan IC regulator yang digunakan 7805 (5 volt). hal ini dikarenakan komponen dan alat ukur yang digunakan masing-masing memiliki toleransi yang menyebabkan tegangan yang keluar pada rangkaian catudaya tidak sama. Namun dengan nilai tegangan 5.4 VDC Masih relatif aman untuk digunakan karena selisih nilainya tidak terlalu besar.

\subsection{Pengujian Mikrokontroler}

Pengujian Mikrokonroler dilakukan untuk mengetahui apakah rangkaian mikrokontroler masih berfungsi dengan baik atau tidak. Pengujian ini dilakukan dengan cara memasukkan program pada mikrokontroler. Program sederhana yang digunakan adalah blink led pada pin D0 NodeMCU. Program blink dapat menjadi program troubleshooting yang dapat digunakan untuk memastikan bahwa mikrokontroler masih berfungsi dengan baik atau tidak. Berikut adalah listing program dari blink led yang ditunujukkan pada gambar 11 dibawah ini.

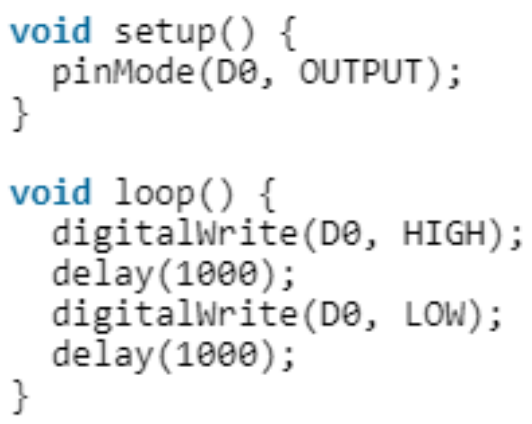

Gambar 11 Listing Program Pengujian Mikrokontroler

\subsection{Pengujian Motor Servo}

Pengujian ini dilakukan untuk mengetahui apakah sudut servo yang diinginkan dengan pergerakannya sesuai atau tidak. Pergerakan servo dikatakan baik apabila nilai error derajat pada servo bernilai rendah.

Pengujian dilakukan dengan menggunakan alat ukur busur derajat guna untuk mengetahui besar pergeseran dari motor servo. Pada program mikrokontroler motor servo disetting melakukan penambahan derajat sebesar 45 dengan waktu delay $3000 \mathrm{~ms}$ (3 detik). Setelah motor mencapai mencapai sudut $180^{\circ}$ maka motor servo akan melakukan pengurangan derajat sebesar $45^{\circ}$ hingga kembali pada posisi $0^{\circ}$.Penggunaan waktu delay sebesar 3 detik guna memberi waktu untuk mengamati besar perubahan motor servo.hasil pengujian motor servo dapat dilihat pada tabel 8 dibawah ini.

\begin{tabular}{ccccc}
\multicolumn{5}{c}{ Tabel } \\
\hline No Hasil Pengujian Motor Servo \\
$\begin{array}{ccccc}\text { Sudut yang } \\
\text { diinginkan }\end{array}$ & $\begin{array}{c}\text { Pembacaan } \\
\text { Alat Ukur }\end{array}$ & $\begin{array}{c}\text { Absolute } \\
\text { Error }\end{array}$ & $\begin{array}{c}\text { Relative } \\
\text { Error (\%) }\end{array}$ \\
\hline 1 & $0^{\circ}$ & $0^{\circ}$ & $0^{\circ}$ & $0 \%$ \\
2 & $45^{\circ}$ & $50^{\circ}$ & $5^{\circ}$ & $11.11 \%$ \\
3 & $90^{\circ}$ & $90^{\circ}$ & $0^{\circ}$ & $0 \%$ \\
4 & $135^{\circ}$ & $140^{\circ}$ & $5^{\circ}$ & $3.7 \%$ \\
5 & $180^{\circ}$ & $185^{\circ}$ & $5^{\circ}$ & $2.77 \%$ \\
\hline
\end{tabular}

Berdasarkan pada hasil pengujian motor servo yang ditunjukkan pada tabel 4maka didapatkan nilai sudut pengukuran yang tidak sesuai diantaranya pada saat posisi sudut 45, 135, dan 180. Namun nilai error masih dalam keadaan relatif kecil yaitu rata-rata memiliki selisih 5 tetapi dengan selisih sudut tersebut masih relatif baik untuk digunakan.

\subsection{Pengujian Koneksi NodeMCU Dengan Menentukan Nilai Waktu Tunda}

Pengujian ini dilakukan untuk mengetahui jarak jangkau maksimum yang mampu diakses oleh mikrokontroller nodeMCU untuk menggerakkan lengan robot dengan menentukan waktu tunda. Proses untuk menentukan nilai waktu tunda ditampilkan pada serial monitor yang ditunjukkan gambar 12 sebagai berikut.

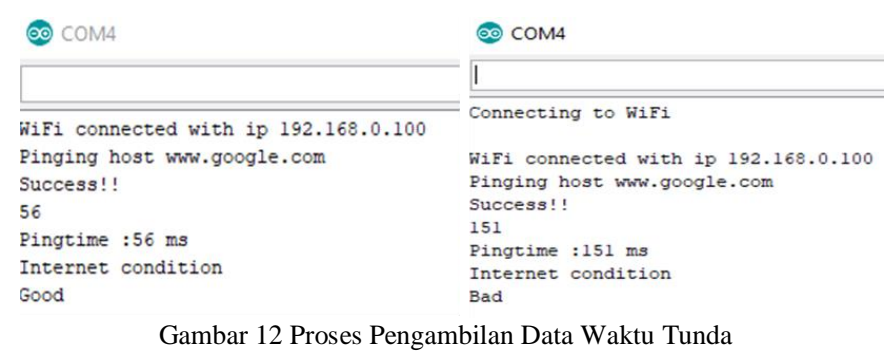

Berdasarkan pada gambar 21 waktu tunda dengan kondisi koneksi yang baik adalah waktu tunda dengan waktu antara $10 \mathrm{~ms}$ hingga $90 \mathrm{~ms}$ semakin rendah nilai waktu tunda maka koneksi semakin bagus. Sedangkan waktu tunda yang semakin besar nilainya maka response penerimaan perintah pada lengan robot akan semakin lambat atau bahkan koneksi gagal tersambung. 
Tabel 9. Hasil Pengujian Jarak Jangkauan Lengan Maksimum terhadap waktu tunda

\begin{tabular}{ccccc}
\hline No & $\begin{array}{c}\text { Jarak } \\
\text { (meter) }\end{array}$ & $\begin{array}{c}\text { Rata-rata } \\
\text { Waktu Tunda } \\
\text { Pingtime }(\mathbf{m s})\end{array}$ & $\begin{array}{c}\text { Kondisi } \\
\text { jaringan }\end{array}$ & Keterangan \\
\hline 1 & 2 & 62.4 & baik & Data terikirm \\
2 & 4 & 61.4 & baik & Data terkirim \\
3 & 6 & 59.4 & baik & Data terikirm \\
4 & 8 & 57.8 & baik & Data terkirim \\
5 & 10 & 56 & baik & Data terikirm \\
6 & 12 & 59 & baik & Data terkirim \\
7 & 14 & 71.8 & baik & Data terikirm \\
8 & 16 & 66.6 & baik & Data terkirim \\
9 & 18 & 79.2 & Kurang Baik & Data Terkirim \\
10 & 20 & 81.4 & Kurang Baik & Data Tidak Terkirim \\
\hline
\end{tabular}

Berdasarkan Pada tabel 9 telah diketahui jarak jangkauan maksimum NodeMCU dengan didapatkan nilai waktu tunda. Jarak jangkauan maksimum NodeMCU untuk menerima perintah melalui jaringan wifi dengan kondisi yang baik yaitu pada jarak 16 meter dengan rata-rata waktu tunda $66.6 \mathrm{~ms}$. pada jarak 18 meter perintah diterima kurang baik terkadang konekti terputus karena kondisi jaringan wifi memilikirata-ata waktu tunda hampir mendekati $80 \mathrm{~ms}$. pada jarak 20 meter perintah sudah tidak dapat diterima oleh NodeMCU karena kondisi jaringan sudah terputus serta mempunyai rata-rata waktu tunda diatas $80 \mathrm{~ms}$.

Berdasarkan pada hasil pengujian yang ditunjukkan pada tabel maka dapat dibuat grafik yang ditunjukkan pada gambar13 dibawah ini.

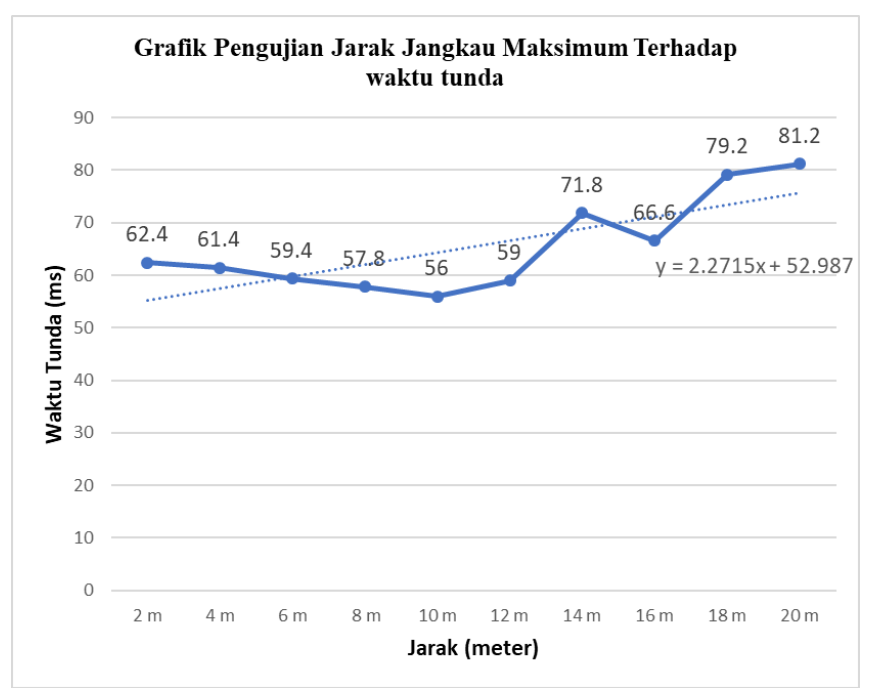

Gambar 13 Grafik Pengujian Jarak Maksimum Terhadap Waktu Tunda

\section{Simpulan}

Berdasarkan hasil pengujian didapatkan nilai beban angkat maximum yang mampu diangkat oleh lengan robot yaitu memiliki berat objek sebesar 33.3 gram dengan dimensi objek 5.7 × 5.2 x 1 . Kemudian pengendalian gerak lengan robotdapat dikendalikan jarak jauh melalui komununikasi Wi-Fi dengan jarak maksimum sejauh 16 Meter dengan nilai rata-rata waktu pengiriman data $66.6 \mathrm{~ms}$ hal ini menunjukkan bahwa kondisi koneksi jaringan wifi masih dalam kondisi baik.

\section{Kepustakaan}

[1] Saefullah Asep, Dewi Immaiar, dan Reza Amar Juliansah. [2015]. "Sistem Kontrol Robot Pemindah Barang Menggunakan AplikasiAndroid Berbasis Arduino Uno”. Vol. 8, No.2 (Januari 2015)

[2] Putra,A.W dan Untoro Djoko. [2015]. "Perancangan Kontroler Lengan Robot Hastobot menggunakan Android dan Arduino dengan komunikasi Bluetooth". Yogyakarta : Program Studi Teknik Elektro Fakultas Sains dan Teknologi Universitas Sanata Dharma. Vol. 8,No.2, 61-70.

[3] Kristyanto, Hendar. [2015]. Lengan Robot Penulis Kata yang Dikendalikan Oleh Aplikasu Pada Android. Skripsi. Tidak Diterbitkan

[4] Andrianto Heri, dan Darmawan Aan, [2016]. "Arduino Belajar Cepat dan Pemrograman". Bandung : Informatika

[5] Syam, Rafiuddin. [2015]. "Kinematika dan Dinamika Robot Lengan". Makassar : Universitas Hasanuddin

[6] Datasheet NodeMCU ESP12, http://www.datasheetnodemcu.com/, diakses tanggal 2 Juli 2018

[7] Datasheet IC AA51880, https://www.digchip.com/datasheets/parts/datasheet/849/AA51880.ph p/, diakses tanggal 2 Juli 2018.

[8] Motor Servo http://elektronika-dasar.web.id/motor-servo/motorservo/, diakses tanggal 2 Juli 2018 